\title{
Examining The Influence Of Social Support and Mentoring On Entrepreneurial Quality Among Graduate Entrepreneurs
}

\author{
Shamsul Huda Abd Rani ,Siti Norasyikin Abd Hamid, Bidayatul Akmal Mustafa Kamil \\ School of Business Management, College of Business, Universiti Utara Malaysia, Sintok, Kedah, Malaysia
}

*Corresponding author: shuda@uum.edu.my

\begin{abstract}
This study investigates the influence of social support and mentoring on entrepreneurial quality among graduate entrepreneurs. In order to gain sustainable growth, entrepreneurial quality is viewed as a crucial factor which affects the business potential such as in overcoming barriers as well as increasing the business survival (Darroch \& Clover 2005). Entrepreneurial quality is essential in increasing the competitiveness of regional economy, not only the competitiveness of the entrepreneurs themselves (Cumplido \& Alcalde 2002). Partial Least Square (PLS) Structural Equation Modeling (SEM) is used to test the relationship between constructs. The findings revealed that social support and mentoring influenced the development of entrepreneurial quality among graduate entrepreneurs.
\end{abstract}

Keywords: Graduate entrepreneurs, entrepreneurial quality, social support, mentoring, partial least square.

(C) 2016 Penerbit UTM Press. All rights reserved

\subsection{INTRODUCTION}

Entrepreneurial quality has been identified as the reason for most of business failure in Previous studies discovered that most of business failures were due to the lack of entrepreneurial quality (Raduan, Kumar \& Yen 2006). This explains why entrepreneurial quality has become the central investigation in entrepreneurship studies (Kuip \& Verheul 2003;Littunen 2010). Entrepreneurial quality as part of the quality of human capital development has become the critical element and the basis for the nation development(Norashidah 2008). According to Kuip and Verheul (2003)the development of entrepreneurial quality is the basis to foster future entrepreneurial behaviour. The way an individual responds to his surrounding heavily depends on his personality.

\subsection{LITERATURE REVIEW}

The GEM report shows that the level of business failure is higher among graduates in comparison to non-graduate entrepreneurs. Based on statistics, the levels of business survival and failure are closely related to the entrepreneurial quality possessed by the graduate entrepreneurs. The level of business failure for graduate entrepreneurs is $2.3 \%$ whereas the level of business failure for non-graduate entrepreneur is $1.7 \%$ (Kwong,Evans \& Brooksbank 2006). The issue of entrepreneurial quality possessed by graduate entrepreneurs becomes the main reason of the higher business failure rate among graduate entrepreneurs than non-graduate entrepreneurs (Kwong et.al .2006). Other than that, graduate entrepreneurs also face performance issue by which their economic contribution appears modest (Kwong et. al 2006).

\section{Graduate Entrepreneurs}

Entrepreneurship education is one of the ways to promote entrepreneurship to young people (Utusan Malaysia 2009).Many efforts, especially for graduates, are done in order to encourage and develop entrepreneurship. Moreover, several approaches have been used by higher education institutions in offering entrepreneurship education. Realizing the importance of having more graduate entrepreneurs, Malaysian government has put efforts in encouraging graduates to become entrepreneurs (Utusan Malaysia 2009). It is believed that graduate entrepreneurs possess the entrepreneurial quality that will lead to entrepreneurial success (Pickernell et.al 2011). Looking at the statistic, scenario and prior discussion on the issue of entrepreneurial quality among graduate entrepreneurs, instead of researching on how to increase the number of graduates to become entrepreneurs in the future, this study is conducted to research on the entrepreneurial quality among the graduate entrepreneurs. 


\section{Social Support}

In this study, two psychosocial factors are identified as antecedents of graduate entrepreneurial quality. Social support is important to human due to its crucial role in the development of a person (Eshbaugh 2010). Social support is particularly unique as relationships are frequently long lasting (Vijver \& Toth 2009). Human quality can be enhanced by social support (Vijver and Toth 2009). In graduate context, graduate entrepreneurs have more advantages in receiving social support from informal networks, friends and family as well as from customers and suppliers compared to non-graduate entrepreneurs (Pickernell et. al 2011). Therefore, it is suggested that social support is one of the key antecedents of entrepreneurial quality and need to be cross-examined in graduate entrepreneur context.

\section{Mentoring}

Due to its importance, mentoring becomes popular to scholars and the practitioners because of its benefits on the human career enhancement and mentoring is seen to increase individual quality (Baugh \& Sullivan 2005;Hamilton 1993). In entrepreneur context, (Richard et. al 2009) pointed that mentoring is beneficial in terms of acquisition of new knowledge, increase confidence and involve in a new relationships. Being graduate entrepreneurs, the advantages of having more networking, resources and access to successful people help them in developing their entrepreneurial quality. Based on the explanation, these hypotheses were developed:

H1: social support influences entrepreneurial quality among graduate entrepreneurs.

$\mathrm{H} 2$ : Mentoring influences influences entrepreneurial quality among graduate entrepreneurs.

\subsection{MEASUREMENT}

The items in the questionnaires taken from other researchers were adapted in graduate entrepreneurship context. Entrepreneurial quality in this study consists of qualities such as need for achievement, locus of control, risk taking propensity, perseverance, independent,creative and knowledgeable. The measurement of constructs for social support was adapted from House (1981).Furthermore, this instrument was also used by Wei and Wang (2009). The measurement of mentoring was adapted from Mathieu (2011).

\subsection{ANALYSIS AND RESULTS}

Data analysis in this study was done using SPSS18.0 (Statistical Package for Social Science) and PLS-SEM. (Partial Least Square-Structural Equation Modelling). The data was keyed-in in the software.. The researcher decided to use Smart PLS software in order to answer the research questions. Specifically, in assessing the validity of the constructs, several analyses were carried out. Convergent and discriminant validity were tested by examining correlation matrix of all the observed variables in order to identify the extent to which different measures of the same construct are highly correlated compared to measures targeted at different constructs. This study used the partial least squares (PLS) in Structural Equation Modelling (SEM) tool to examine the factors influencing entrepreneurial quality among graduate entrepreneurs.

\section{Reliability and Validity}

To determine individual item reliabilities the researcher looked at their loadings to their respective constructs. The composite reliability values also range from 0.87 to 0.93.Sekaran and Bougie (2010) claimed that construct validity is testing how well the results obtained from the use of the measure fit the theories around which the test is designed. Construct validity can be assessed through convergent and discriminant validity (Hair et. al 2010). First the loadings and cross loadings have to be checked to assess if there are problem with any items. A cut-off value for loading at 0.50 is chosen as significant (Hair et. al 2010). All items load highly on that construct and load lower on the other constructs thus confirming construct validity.

Convergent validity is the degree to which multiple items measuring the same concept are in agreement. Hair et. al (2010) suggested that factor loadings, composite reliability and average variance are needed in order to assess convergent validity. The loadings for all items exceed the recommended value of 0.50 . Composite reliability values in indicate all constructs range from 0.87 to 0.93 which also exceed the recommended value of 0.70 (Hair et. al 2010). The average variance extracted (AVE) measures the variance captured by the indicators relative to measurement error. AVE thus, should be greater than 0.50 . In this study, the average variance extracted is in the range of 0.50 to 0.67 .

The discriminant validity is assessed by examining the correlations between the measures of potentially overlapping constructs (MacKenzie et. al 2011).According to Compeau et. al (1999), items should load more strongly on their own constructs and the average variance shared between each construct and its measures should be greater than the variance shared between the construct and other constructs. In summary, in this study the measurement model demonstrated adequate convergent validity anddiscriminant validity.

\section{Assess the significance and relevance of the structural model relationships}

After analyzing the Measurement Model, the next step in a PLS Analysis is to create a structural model, by analyzing the inner model. To test for significance, all of the data were run using 500 bootstrapped samples. In this study social support is positively related $(\beta=0.222$, $\mathrm{p}<0.05)$ to entrepreneurial quality among graduate entrepreneurs. Mentoring is positively related $(\beta=0.300, p<0.05)$ to entrepreneurial quality among graduate. Predictive power of the structural model can be assessed by the $\mathrm{R}^{2}$ value of the endogenous construct. In this study, the $\mathrm{R}^{2}$ value is 0.25 suggesting that $25 \%$ of the variance. 


\subsection{DISCUSSION}

\section{Social Support and Entrepreneurial Quality Among Graduate Entrepreneurs}

It is hypothesized that social support has influence on entrepreneurial quality among graduate entrepreneurs. The findings of this study show that social support is positively related to the entrepreneurial quality among graduate entrepreneurs. The concern they receive for their happiness and health makes them feel good and comfortable. This helps in increasing entrepreneurial quality among graduate entrepreneurs. This is supported by (Pickernell et. al 2011) who pointed that graduate entrepreneurs have advantage in terms of receiving beneficial supports from informal networks or trade associations, family and friends at national or international level. Being graduates, they were exposed to the university life of which they always gain support from family, friends and colleagues in order to survive and to succeed during their studies. Therefore in doing business, the social support is always needed in order to develop good quality in them.

\section{Mentoring and Entrepreneurial Quality Among Graduate Entrepreneurs}

Ragins and Cotton (1999) claimed that a mentor may act as a teacher to enhance a person's skills and intellectual development. Additionally, Beckett (2010) pointed that successful mentoring has long term effects since it helps mentees to grow and develop the quality to become mentors of tomorrow. From the findings, mentoring is significantly related to entrepreneurial quality among graduate entrepreneurs in supplying information on the business world, suggesting other points of view, reassuring the graduate entrepreneurs and putting them into contact with people the mentors know. This is supported by Pickernell et.al (2011) claimed that graduate entrepreneurs have advantage of having a wide networks and resources. Therefore, having the advantage of access to successful entrepreneurs, the graduate entrepreneurs are believed to have mentors who can help them to develop and increase their entrepreneurial quality.

\subsection{CONCLUSION}

The quality of human capital development has become the critical element and the basis for the nation development (Norashidah 2008). From the findings of this study, the researcher concludes that entrepreneurial quality among graduate entrepreneurs play an important role in determining entrepreneurial success. The presence of social support and mentoring in this study are found to contribute to entrepreneurial quality in graduate entrepreneurs.

\section{References}

Baugh,S.G. \& Sullivan, S.E. (2005). Mentoring And Career Development. Career Development International, 10(67), 425-428.

Beckett, B.J. 2010. Mentorship Is Key To Career Success. Strategic Finance, 21-22.

Compeau, Deborah,Higgins, Christopher,Huff \& Sid. (1999). Social Cognitive Theory and Individual Reactions to Computing Technology:A longitudinal Study.Managment Information System, 23(2).

Cumplido, F.J.S. \& Alcalde, F.L. (2002). Towards An Empirical Methodology For The Measurement Of The Quality Entrepreneur: The Case Of Sevillian Entrepreneurs. 42nd ERSA Conference. Dortmund. 27-31 August 2002.

Cumplido, F.J.S. \& Linan,F. (2006). Measuring Entrepreneurial Quality in Southern Europe. International Entrepreneurial Management Journal 3: 87-10.

Dana (2001). The Education And Training Of Entrepreneurs in Asia. Education+Training 43 8/9, 405-415.

Darroch,M. \& Clover,TA. (2005).The Effects Of Entrepreneurial Quality On The Success Of Small, Medium And Micro Agri-Businesses in Kwazulu-Natal, South Africa. Journal of Agrekon 44(3), 321-338.

Eshbaugh, E.M. (2010). Friend and Social support as Moderators of the Effects of Low Romantic Partner Support on Loneliness Among College Women. Individual Differences Research 8 (1), 8-16.

Hair, J. Samuoel, P., Page, M \& Money A. (2010). Research Methods For Business. England: John Wiley\&Sons Ltd.

Hamilton, R. (1993). Mentoring. Pelanduk Publication. Petaling Jaya, Malaysia.

House, J.S. 1981. Social Support And Individual Environment. Sociological Forum 2(1), 225- 246.

Kwong,C., Evans,D.J. \& Brooksbank, D. (2006). The State Of Graduate Entrepreneurship in the UK-Preliminary Policy Paper Based on GEM 2005 data. GEMWales Working Paper Series. United Kingdom.

Kuip, I.V.D. \& Verheul, I. (2003). Early Development of Entrepreneurial quality: The Role of Initial Education. Scientific Analysis of Entrepreneurship and SMEs

Littunen, H. 2010. Entrepreneurship And The Characteristics Of The Entrepreneurial Personality. International Journal of Entrepreneurial Behavior and Research, (6), 295-309.

MacKenzie,S.B.,Podsakoff, P.M.,Podsakoff,N.P (2011). Construct Measurement And Validation Procedures in MIS and Behavioral Research: Integrating New And Existing Techniques. MIS Quarterly, 35(2), 293-334.

Mathieu, C. (2011). The Influence Of Mentoring On Mentee's Satisfaction And Career: The Role Of Entrepreneurial Self Efficacy. USASBE-2011 Proceedings.

Norashidah Hashim (2008). Kesediaan Pelajar dan Persekitaran Dalaman Institusi Pengajian Tinggi Awam Terhadap Pendidikan Keusahawanan. Tesis Dr. Fal, Universiti Kebangsaan Malaysia. 2009.

Pickernell, D., Pacham, G., Jones, P., Miller, C. \& Thomas, B. 2011.Graduate entrepreneurs are different: They access more resources? International Journal of Entrepreneurial Behavior and Research, 1-16.

Raduan, Kumar \& Yen. (2006). Entrepreneurs Success Factors and Escalation of Small and Medium-sized Enterprise in Malaysia. Journal of Technology Management and Entrepreneurship, 4(1), 1-24.

Ragins, G \& Cotton,G. (1999). Mentoring In The Developing World:Intentions, Education And Development. International Journal of Entrepreneurial Behavior and Research (6).

Richard, O.C., Briltian,S. Fay,K. (2009). The Importance Of Mentoring For Individuals And Organizations. Development and Learning in Organization, 24(3).

Sekaran \& Bougie (2010). Research Methods For Business: A Skill Building Approach. John Wiley \& Sons, New York.

Sullivan, R. (2000). Entrepreneurial Learning And Mentoring. International Journal ofEntrepreneurial Behavior \& Research, 6(3), 160-175.

Sullivan, S.E. \& Baugh, S. G. (2005). Mentoring And Career Development. CareerDevelopment International 10(6), 425-428.

Toth, J.V.A. \& Vijver, F.J.R. (2009). Social Support In Five Cultural Groups in the Netherlands. Journal of Comparative Family Studies, 455-473.

Utusan Malaysia (2009).Graduan Harus Jadi Penggerak Barisan Hadapan Untuk Mencapai MBE. Utusan Malaysia, 15 Mei 2010.

Vijver,F.J.R. \& Toth, J.V.A. (2009). Family Support In Five Cultural Groups In the Netherland. Department of Psychology, 10(3), 120-132.

Wei, X. \& Wang, C. (2009). Research on the Contents and Structure of Social support for Private Enterpreneurs. Asian Social Science. 5(2). 